\title{
Implementasi Akad Ijarah Muntahiya Bi Al-Tamlik (IMBT) Perspektif Fatwa DSN-MUI Nomor 27 Tahun 2002 \& Hukum Islam
}

\author{
Implementation of the Ijarah Muntahiya Bi Al-Tamlik Agreement \\ according to the DSN-MUI Decree Number 27 of 2002 and Islamic Law
}

\author{
Jamaluddin \\ Institut Agama Islam Tribakti Kediri \\ Jamaluddin.bukhoriO2@gmail.com
}

\begin{abstract}
The Ijarah Muntahiya bi al-Tamlik (IMBT) contract is a lease agreement that ends with the transfer of property rights by means of sale and purchase (grant) at the end of the lease period. In the perspective of Islamic law, the IMBT contract is in accordance with the principles, pillars, and some terms of the contract. Unfulfilled contract conditions, namely the requirement for legal certainty. Meanwhile, in the perspective of the DSN-MUI Fatwa Number 27/2002 and Islamic Law, the IMBT agreement is an anonymous agreement that arises from the existence of the principle of freedom of contract. The IMBT contract is in accordance with the terms and elements of the agreement. IMBT legal consequences are rights and obligations. This scientific paper will examine the normative and applicable aspects of law. Legal norms that are included in the realm of unwritten law in the context of laws and regulations in Indonesia concerning Sharia Economics are DSN-MUI fatwas, especially regarding IMBT which has been perceived as a national law, (Law Number 21 of 2008, concerning Islamic Banking), Bank Regulations Indonesia (BI), the Financial Services Authority (OJK) and Sharia Financial Institutions (KLS) as an effort to apply the law in an applicative manner.
\end{abstract}

Keywords: Ijarah Muntahiya Bi Al-Tamlik Agreement, DSN MUI Decree Number 27 of 2002 and Islamic Law 
Jamaluddin | Implementasi Akad Ijarah...

\begin{abstract}
Abstrak
Akad Ijarah Muntahiya bi al-Tamlik (IMBT) merupakan akad perjanjian sewa-menyewa yang diakhiri pemindahan hak milik barang dengan cara jual-beli (hibah) di akhir masa sewa. Dalam prespektif hukum Islam akad IMBT sudah sesuai dengan asas, rukun, dan sebagian syarat akad. Syarat akad yang tidak terpenuhi, yaitu syarat adanya kepasti an hukum. Sedangkan dalam prespektif Fatwa DSN-MUI Nomor 27/2002 dan Hukum Islam, perjanjian IMBT merupakan perjanjian tidak bernama yang timbul dari adanya asas kebebasan berkontrak. Akad IMBT sudah sesuai dengan syarat dan unsur-unsur perjanjian. Akibat hukum IMBT yaitu hak dan kewajiban. Karya ilmiah ini akan mengkaji aspek normatif dan aspek aplikatif hukum. Norma hukum yang termasuk ranah hukum tidak tertulis dalam konteks peraturan perundang-undangan di Indonesia tentang Ekonomi Syariah adalah fatwa DSN-MUI, khususnya tentang IMBT yang telah dipersepsikan ke dalam hukum nasional, (UU Nomor 21 Tahun 2008, tentang Perbankan Syariah), Peraturan Bank Indonesia (BI), Otoritas Jasa Keuangan (OJK) dan Lembaga Keuangan Syariah (KLS) sebagai upaya penerapan hukum secara aplikatif.
\end{abstract}

\title{
Kata Kunci: Akad Ijarah Muntahiya Bittamlik (IMBT), Fatwa DSN-MUI dan Hukum Islam.
}

\section{Pendahuluan}

Eksistensi Ijarah Muntahiya bi al-Tamlik (IMBT), baik secara filosofis, yuridis, maupun sosiologis telah diakui di Indonesia. Secara filosofis, IMBT diakui sebagai hukum yang sesuai dengan cita-cita hukum yang bernilai positif, terutama dalam konteks kesejahteraan. Secara yuridis, IMBT diakui sebagai salah satu akad penyaluran dana bank syariah. ${ }^{1}$ Sedangkan secara sosiologis, IMBT diakui sebagai hukum yang telah diterima oleh masyarakat. ${ }^{2}$

\footnotetext{
${ }^{1}$ Undang-undang Nomor 21 Tahun 2008 tentang Perbankan Syariah, pasal 19 ayat (1) huruf f, ayat (2) huruf f dan pasal 21 huruf b4.

2 Soerjono Soekanto dan Mustafa Abdullah, Sosiologi Hukum Masyarakat dalam Masyarakat, (Jakarta: Rajawali Pers, 1987), hlm. 13.
} 
Setelah ditetapkanya Fatwa DSN Nomor 27/DSN-MUI/III/ 2002 tentang IMBT. Oleh karena itu salah satu jasa yang dikembangkan alam ekonomi syariah adalah produk IMBT. ${ }^{3}$

Dinamika pemikiran fiqhiyah dalam bersinggungan antara prinsip syariah dan perkembangan sistem keuangan kontemporer mengalami perkembangan kemajuan yang luar biasa. Dalam hukum positif, akad sewamenyewa yang diatur dalam KUHPerdata dikembangkan menjadi akad leasing sehingga terlahir konsep operating lease dan financial lease serta berbagai derivasinya. ${ }^{4}$

Pada makalah ini penulis akan menjelaskan hubungan (titik singgung) antara ketentuan ijarah (terutama ijarah atas manfaat barang (ijarat al-a'yan) dan ajaran sewa guna usaha (pembiayaan) dalam rangka penyediaan barang modal. Secara konseptual, leasing merupakan titik temu antara akad sewa dan akad jual-beli. Sedangkan dalam perspektif khasanah fiqh, akad ijarah dikembangkan menjadi akad Ijarah Muntahiyyah bi al-Tamlik (IMBT). ${ }^{5}$

Lembaga Keuangan Syariah (LKS), baik bank maupun non bank saat ini banyak yang menerapkan dan mengembankan produknya sebagai upaya strategis untuk meningkatkan layanan kepada masyarakat. Salah satu akad yang paling urgen adalah akad Ijarah Muntahiya Bittamlik (IMBT) dan Musyarakah Mutanaqishah (MMQ), tetapi penulis akan membahas tentang akad Ijarah Muntahiya bi al-Tamlik (IMBT) saja sesuai dengan Fatwa DSNMUI Nomor : 27/2002.

3 Al-Ma'asyir al-Syar'iyyah, (Bahrain: Hai'at al-Muhasabah wa al-Muraja'ah li alMu'assasat al-Maliyah al-Islamiyyah, 2006), hlm. 131-153.

4 Jaih Mubarok dan Hasanudin, Fiqh Muamalah Malyyah : Akad Ijarah dan Ju'alah, (Bandung: Simbiosa Rekatama Media, 2017), hlm.93.

5 Jaih Mubarok dan Hasanudin, Fiqh Muamalah Malyyah : Akad Ijarah dan Ju'alah, (Bandung: Simbiosa Rekatama Media, 2017). 


\section{Jamaluddin | Implementasi Akad Ijarah...}

Inti point Fatwa DSN 27/DSN-MUI/III/ 2002 : tentang al-Ijarah alMuntahiyah bi al-Tamlik (IMBT) adalah, sbb :

Pertama : Ketentuan Umum

Akad al-Ijarah al-Muntahiyah bi al-Tamlik (IMBT) boleh dilakukan dengan ketentuan sebagai berikut :

1. Semua rukun dan syarat yang berlaku dalam akad Ijarah (Fatwa DSN 09/DSN-MUI/IV/2000) berlaku pula dalam akad al-Ijarah al-Munta-hiyah bi al-Tamlik (IMBT).

2. Perjanjian untuk melakukan akad al-Ijarah al-Muntahiyah bi al-Tamlik (IMBT) harus disepakati ketika akad Ijarah ditandatangani.

3. Hak dan kewajiban setiap pihak harus dijelaskan dalam akad.

Kedua : Ketentuan tentang al-Ijarah al-Muntahiyah bi al-Tamlik (IMBT).

1. Pihak yang melakukan al-Ijarah al-Muntahiah bi al-Tamlik (IMBT) harus melaksanakan akad Ijarah terlebih dahulu. Akad pemindahan kepemilikan, baik dengan jual beli atau pemberian (hibah), hanya dapat dilakukan setelah masa Ijarah selesai.

2. Janji pemindahan kepemilikan yang disepakati di awal akad Ijarah adalah al-wa'd (الوعد), yang hukumnya tidak mengikat. Apabila janji itu ingin dilaksanakan, maka harus ada akad pemindahan kepemilikan yang dilakukan setelah masa Ijarah selesai.

\section{Ketiga :}

1. Apabila salah satu pihak tidak menunaikan kewajibannya atau apabila terjadi perselisihan di antara kedua belah pihak, maka penyelesaianya dilakukan melalui Badan Arbitrasi Syari'ah (BASYARNAS) setelah tidak tercapai kesepakatan melalui musyawarah. 
2. Fatwa ini berlaku sejak tanggal ditetapkan dengan ketentuan apabila di kemudian hari ternyata terdapat kekeliruan dalam fatwa ini, akan diubah dan disempurnakan sebagaimana mestinya. ${ }^{6}$

Sesuai dengan Undang-undang Nomor 21 Tahun 2008 tentang Perbankan Syariah dan diataur dalam al-Qur'an dan al-Hadist. Karya ilmiah ini bertujuan untuk memahami pelaksanaan akad Ijarah Muntahiyah bi alTamlik (IMBT) dan bentuk akad Ijarah Muntahiyah bi al-Tamlik (IMBT) pada Lembaga keuangan syariah (LKS), baik bank maupun non bank.

Metode pendekatan yang digunakan dalam karya ilmiah ini adalah metode pendekatan kualitatif, yuridis dan empiris. Merupakan metodologi (prosedur) yang digunakan untuk memecahkan masalah karya ilmiah dengan meneliti data skunder terlebih dahulu untuk kemudian dilanjutkan dengan mengadakan penulisan terhadap data primer di kepustakaan, sehingga dari penulisan karya ilmiah ini yang dilakukan dapat diperoleh hasil karya ilmiah dan kesimpulan yang baik. Berdasarkan hasil penulisan karya ilmiah ini yang dilakukan melalui library research, maka diperoleh tahapan-tahapan (prosedur) pelaksanaan Ijarah Muntahiyah bi al-Tamlik (IMBT) dengan baik, inovatif dan dinamis.

Akad Ijarah Muntahiya bi al-Tamlik (IMBT) dan Musyarakah Mutanaqishah (MMQ) sesungguhnya akad yang sophisticated (canggih), karena dapat digunakan untuk berbagai macam produk perbankan syariah, setidaknya dapat digunakan untuk 15 (lima belas) macam produk perbankan syariah, seperti : refinancing, working capital, take over (top up), KPR Indent, investasi indent, penagihan hutang dari bank konvensional ke bank syariah,

6 Dewan Syariah Nasional Majelis Ulama Indonesiai (DSN-MUI), (Jakarta: ditetapkan di Jakarta, tanggal: 14 Muharram 1423 H / 28 Maret 2002 M. 


\section{Jamaluddin | Implementasi Akad Ijarah...}

restrukturisasi pembiayaan (konversi akad), capital expenditure (investasi), reimbursement, pembiayaan konsumtif untuk KPRS, dll.

Akad Ijarah Muntahiya bi al-Tamlik (IMBT) dan Musyarakah Mutanaqishah (MMQ) sudah diterapkan di banyak negara di dunia. Di Indonesia sudah berjalan selama \pm 22 (dua puluh dua) tahun, seharusnya sudah dapat diterapkan oleh Lembaga Keuangan Syariah (LKS) dan bank-bank syariah lainya di Indonesia agar bank syariah tersebut bisa lebih kompetitif, dinamis, inovatif dan diminati oleh masyarakat publik dengan tersedianya berbagai produk perbankan syariah yang luwes dan luas.

Pembanguanan nasional dilaksanakan dengan baik dan linier oleh sektor pemerintah maupun swasta. Hal ini merupakan salah satu upaya pembangunan yang berkesinambungan, baik pembangunan fisik maupun nonfisik. Pembangunan nasional salah satunya ditandai dengan pertumbuhan dan perkembangan ekonomi Indonesia yang pada umumnya tidak dapat dipisahkan dari kegiatan ekonomi melalui jasa financial perbankan. Bank merupakan lembaga keuangan mempunyai peranan yang sangat strategis dimana kegiatan utama dari perbankan adalah menyerap dana dari masyarakat dan menyalurkan kembali kepada masyarakat. ${ }^{7}$

Lembaga Keuangan Syariah (LKS) sudah banyak yang menggunakan pembiayaan akad Ijarah Muntahiya bi al-Tamlik (IMBT). Pada operasionalnya, pembiayaan IMBT ini menggunakan tiga akad, yaitu akad jual-beli, IMBT dan Hibah. Sebelum melakukan akad IMBT ini nasabah yang mengajukan pembiayaan terlebih dahulu menjual barang yang akan disewa olehnya kepada pihak bank menggunakan akad jual-beli.

\footnotetext{
${ }^{7}$ Rastono, Penerapan Prinsip Bagi Hasil dalam Pembiayaan Terhadap Nasabah Bank Syariah, Tesis tidak diterbitkan, (Semarang, Fakultas Hukum Universitas Diponegoro, 2008), hlm 1 .
} 
Hal tersebut sedikit berbeda, apabila dilihat dari Fatwa DSN-MUI Nomor : 27/2002 tentang al-Ijarah al-Muntahiyah bi at-Tamlik bahwa dalam ketentuan Fatwa DSN-MUI tersebut akad yang digunakan antara nasabah dengan bank hanya ditetapkan dua akad, yaitu akad IMBT sebagai akad sewa, akad jual-beli (hibah) sebagai akad pemindahan kepemilikan barang terhadap objek sewa.

Tulisan ini bertujuan untuk mengetahui bagaimana implementasi akad Ijarah Muntahiya bi al-Tamlik (IMBT) di Lembaga Keuangan Syariah (LKS) dan bagaimana kesesuaian antara pelaksanaan akad Ijarah Muntahiya bi alTamlik (IMBT) dengan Fatwa DSN-MUI Nomor 27/2002. Kerangka dasar pemikiran dalam tulisan ini didasarkan pada kedudukan Fatwa DSN-MUI Nomor 27/2002 dan prinsip dasar dalam bermuamalah.

Transaksi dalam muamalah setidaknya harus memenuhi empat prinsip dasar, yaitu: Pertama, muamalah boleh dilakukan kecuali ada dalil yang melarangnya. Kedua, muamalah itu hendaknya dilakukan dengan suka sama suka. Ketiga, muamalah hendaknya mendatangkan mashlahat dan menolak madharat. Keempat, muamalah itu terhindar dari unsur gharar, riba, kezaliman dan unsur lain yang diharamkan berdasarkan syara' ${ }^{8}$

Metode penulisan makalah ini menggunakan metode deskriptif, yaitu suatu metode penulisan dengan cara mengumpulkan, mengolah, dan menganalisa data. Adapun metode pengumpulan data yang digunakan adalah dokumentasi dan studi kepustakaan.

Penelitian ini dapat disimpulkan bahwa Implementasi Akad Ijarah Muntahiya bi al-Tamlik (IMBT) Perspektif Fatwa DSN-MUI Nomor 27/2002, dan Hukum Islam, telah sesuai dengan prinsip-prinsip muamalah.

8 Ahmad Hasan, Nazhariyyat al-Ujur fi al-Fiqh al-Islami: Dirasah Tahliliyyah Mubtakirah li-Fiqh al-Muamalat al-Maliyah, (Damaskus: Dar al- Iqra', t.th), hlm. 143-182 


\section{Jamaluddin | Implementasi Akad Ijarah...}

Akad Ijarah Muntahiya bi al-Tamlik (IMBT) ini selain diterapkan dalam pembiayaan IMBT murni, juga diterapkan dalam pembiayaan IMBT yang bertujuan untuk pembiayaan ulang (Refinancing) dengan mengguna-kan skema al-ba'i wal isti'jar. ${ }^{9}$

al-Bai' wal isti'jar (sale and lease back) menurut fatwa DSN-MUI adalah jual beli suatu aset yang kemudian pembeli menyewakan aset tersebut kepada penjual. Akad Ijarah baru dapat dilakukan setelah terjadi jual-beli atas aset yang akan dijadikan sebagai obyek.

Fatwa Dewan Syari'ah Nasional Nomor 89/DSN-MUI/XII/2013 tentang Pembiayaan Ulang (Refinancing) Syariah muncul sebuah pernyataan dan pertanyaan :

1. Di kalangan masyarakat muncul pertanyaan tentang transaksi pembia-yaan ulang (Refinancing) yang sesuai dengan prinsip syariah,

2. Ketentuan tentang transaksi pembiayaan ulang (refinancing) yang berdasarkan prinsip syariah belum diatur dalam fatwa DSN-MUI,

3. Berdasarkan pertimbangan sebagaimana dikemukakan diatas, maka DSN MUI memandang perlu menetapkan fatwa tentang pembiayaan ulang refinancing) yang berdasarkan prinsip syariah,

4. Berdasarkan pertimbangan sebagaimana dikemukakan dalam di atas, maka DSN-MUI memandang perlu menetapkan fatwa tentang pem-biayaan ulang (refinancing) syariah untuk dijadikan pedoman bagi Lembaga Keuangan Syariah (LKS).

Sedangkan ketentuan dalam pelaksanaanya telah sesuai dengan rukun dan syarat Fatwa DSN-MUI Nomor 27/2002 tentang al-Ijarah al-Munta-

9 Muhammad Yusuf Arif al-Haj Muhammad, Aqd al-Ijarah al-Muntahiyyah bi alTamlik min al-Tathbiqat al-Mu'ashirah li Aqd al-Ijarah fi Fiqh al-Islami, (Gazza: Universitas al-Najah al-Wathaniyyah, 2003), hlm. 173-176 
hiyah bi at-Tamlik dan Fatwa DSN-MUI Nomor 89/2013 tentang Pembiayaan Ulang (Refinancing) Syariah.

\section{Pengertian Leasing dan IMBT.}

\section{a. Pengertian Leasing}

Istilah leasing berasal dari kata lease yang berarti sewa-menyewa. Oleh karena itu leasing dapat disebut sebagai bentuk derivatif dari perjanjian sewamenyewa (perjanjian sewa guna usaha). Dengan demikian leasing berarti equipment funding, yaitu pembiayaan peralatan (barang modal) untuk digunakan pada proses produksi suatu perusahaan, baik langsung maupun tidak langsung. ${ }^{10}$ Dalam praktiknya, leasing menjadi bentuk pembiayaan perusahaan yang pada umumnya dilakukan oleh perusahaan pembiayaan.

Dengan demikian arti leasing adalah "setiap kegiatan pembiayaan perusahaan dalam bentuk penyediaan barang-barang modal untuk diguna-kan oleh suatu perusahaan dalam jangka waktu tertentu, berdasarkan pembayaran secara berkala disertai dengan hak pilih (opsi) dari perusahaan tersebut untuk membeli barang-barang modal yang bersangkutan atau memperpanjang jangka waktu leasing berdasarkan nilai sisa yang telah disepakati bersama" ${ }^{11}$

Dari definisi ini leasing terdapat 6 (enam) istilah teknis yang layak untuk dipahami bersama untuk lebih mendalam, di antaranya :

\section{Pembiayaan Perusahaan}

Pembiayaan leasing diperuntukkan perusahaan-perusahaan yang memerlukan barang modal. Namun perkembanganya, pembiayaan leasing disalurkan juga kepada individu (bukan perusahaan) yang memerlukan

\footnotetext{
10 Amin Widjaya Tunggal dan Arif Johan Tunggal, Aspek Yuridis dalam Leasing. (Jakarta: PT Renika Cipta, 2001), hlm. 7.

11 Munir Fuady, Hukum tentang Pembiayaan dalam Teori dan Praktik, (Bandung: PT Citra Aditya Bakti, 2002), hlm. 9
} 
Jamaluddin | Implementasi Akad Ijarah...

pembiyaan pembangunan rumah kost, kendaraan bermotor, mobil dll. yang tidak dijadikan barang modal.

\section{Penyediaan Barang Modal}

Keputusan Menteri Keuangan Nomor 1169/KMK/01/1991 mendefinisikan bahwa barang modal adalah setiap aktiva tetap yang berwujud, termasuk tanah, sepanjang di atas tanah tersebut melekat tetap berupa bangunan (plan), tanah serta aktiva dimaksud merupakan satu kesatuan kepemilikan yang mempunyai masa manfaat lebih dari satu tahun dan digunakan secara langsung untuk menghasilkan, meningkatkan, memperlancar produksi barang dan jasa oleh penerima sewa.

\section{Pembatasan Jangka Waktu}

Dalam perjanjian leasing harus ditentukan jangka waktunya. Dalam Keputusan Menteri Keuangan Nomor 1169/KMK/01/1991 Keputusan Menteri Keuangan Nomor 1169/KMK/01/1991 dikenalkan tiga macam jangka waktu

leasing minimal 3 (tiga) tahun, yaitu : 1) dalam waktu singkat (minimal 2 tahun), 2) waktu menengah (minimal 3 tahun), 3) waktu panjang (minimal tujuh tahun).

\section{Pembayaran Kembali Secara Berkala}

Pemberi sewa telah membayar lunas kepada pemasok atas pembelian barang modal, maka barang modal sudah menjadi milik pemberi sewa. Karena itu penerimaan sewa harus membayar sewa atas penggunaan barang modal tersebut.

\section{Hak Opsi untuk Membeli Barang Modal}

Hak opsi dimiliki penerima sewa untuk membeli barang modal pada saat tertentu dengan syarat tertentu. Opsi yang dimiliki penerima sewa adalah membeli barang modal pada akhir sewa dan memperpanjang jangka waktu sewa. 
Jamaluddin | Implementasi Akad Ijarah...

\section{Nilai Sisa (Residu)}

Besarnya jumlah uang yang harus dibayar kembali kepada pemberi sewa oleh penerima sewa pada akhir berlakunya masa sewa. Besaran nilai sisa pada umumnya sudah terlebih dahulu ditentukan dalam akta perjanjian leasing. ${ }^{12}$

Subyek hukum dalam usaha leasing adalah lessor (pemberi sewa) dan lesse (penerima sewa). Sedangkan dalam praktiknya memerlukan pihak ketiga, yaitu supplier. Orientasinya adalah sebagai berikut :

○ Pemberi Sewa adalah pihak yang yang memberikan pembiayaan dengan cara leasing kepada pihak yang membutuhkanya,

○ Penerima Sewa adalah pihak yang memerlukan barang modal yang dibiayai oleh pemberi sewa,

○ Supplier (pemasok) barang adalah pihak yang menyediakan barang modal yang menjadi obyek akad leasing. ${ }^{13}$

\section{b. Pengertian IMBT}

Akad Ijarah Muntahiyyah Bittamlik (IMBT) termasuk akad mustahdatsah (mustajaddah) akad baru yang diduga kuat hasil interaksi antara fiqh dan pranata bisnis leasing yang hidup dan berkembang di masyarakat yang menyebut perjanjian leasing sebagai pranata "banci" karena mengandung 2 (dua) unsur hukum yang berbeda : 1) unsur sewa-menyewa, sebagaimana diatur dalam KUHPerdata, 2) unsur jual-beli (al-bai') yang juga diatur dalam KUHPerdata juga dalam bab dan pasal yang berbeda-beda. ${ }^{14}$

Dalam perspektif teori perjanjian, akad IMBT pada prinsipnya merupakan perpaduan antara akad mu'awadhat dan akad tabarru' (akad

12 Munir Fuady, Hukum tentang Pembiayaan dalam Teori dan Praktik, (Bandung: PT Citra Aditya Bakti, 2002), hlm. 7-12

13 Munir Fuady, Hukum tentang Pembiayaan dalam Teori dan Praktik, hlm. 8-9

14 Munir Fuady, Hukum tentang Pembiayaan dalam Teori dan Praktik, hlm. 5 


\section{Jamaluddin | Implementasi Akad Ijarah...}

hibah) yang diselingi dengan janji bersyarat (wa'd bi syarth). Akad Mu'awadhah adalah akad yang dilakukan karena adanya motif bisnis, seperti jual beli, sewa-menyewa atau lainnya sehingga cara yang ditempuh dapat berupa pertukaran harta dengan uang atau uang dengan jasa (sewa benda ujrah (upah) untuk tenaga).

Kaidah seputar jual-beli terkait prinsip dalam akad muawwadhat dan akad tabarru' menyatakan sbb :

$$
\text { عقود المعاوضات مبناها على المشاحة, وحقوق التبر عات مبناها على المسامحة }
$$

Artinya: "Akad muawwadhat dibangun atas prinsip al-Musyahah, sementara akad tabarru' dibangun di atas toleransi". Kata al-Musyahah berasal dari kata as-Syuh (الثح) yang artinya pelit.

Dalam fiqih muamalah maliyah (muamalah terkait harta benda), ada 4 (empat) pembagian akad, dilihat dari objeknya, sebagai berikut :

1. Akad Muawwadhat

Transaksi yang tujuan utamanya mendapatkan iwadh (ganti), keuntungan berupa uang/barang/jasa, yang dilakukan secara dua arah. Seperti, jualbeli, sewa-menyewa, dst.

2. Akad Tabarru' (Sosial)

Akad yang tujuan utamanya untuk sosial, menolong, berbuat baik kepada sesama, sehingga dilakukan searah. Misalnya hibah, sedekah, pinjaman, termasuk memberi pinjaman uang (utang) al-Qard/Qard al-Hasan.

3. Akad Musyarakat

Transaksi yang tujuannya mendapat keuntungan, dengan menggabungkan peran banyak pihak, untuk bersama-sama mendapatkan keuntungan. Seperti: mudharabah, musyarakah, ijarah (sewa-menyewa) dst. 
Jamaluddin | Implementasi Akad Ijarah...

\section{Akad Tautsiqat}

Akad yang tujuan utamanya untuk menjamin keamanan suatu transaksi. Sehingga yang bersangkutan tidak menjadi tujuan utama, namun sebatas penjamin transaksi lainnya. Seperti akad dhiman (jaminan), kafalah, gadai, dst.

Dengan demikian apabila dikerucutkan, dari keempat akad tersebut dapat kelompokan menjadi dua kategori :

1. Akad yang motifnya komersial, yaitu akad muawwadhat.

2. Akad yang motifnya sosial, yaitu akad tabarru'.

Dari kedua akad tersebut, yaitu akad muawwadhat, prinsip penting yang perlu dikedepankan adalah saling ridha, sebagaimana firman Allah swt. dalam al-Qur'an surat an-Nisa' ayat $29 \mathrm{sbb}$ :

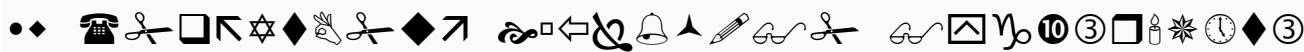

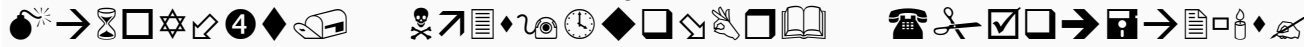

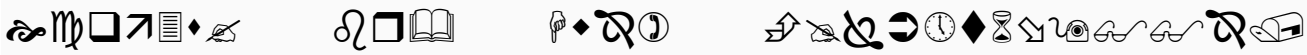
$\cdots \bullet \square$ 闻

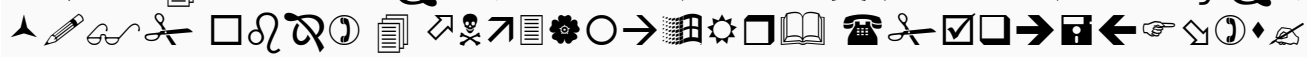

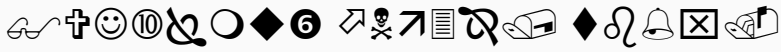

Terjemahnya: “Wahai orang-orang yang beriman, janganlah kamu saling memakan harta sesamamu dengan jalan yang batil, kecuali dengan jalan perniagaan yang berlaku dengan suka sama-suka di antara kaтu. dan janganlah kaтu membunuh dirimu. Sesungguhnya Allah adalah Maha Penyayang kepadamu"15 (QS. an-Nisa', 29).

Para ulama menyebutkan bahwa untuk dapat disebut saling ridha (antaradhin) itu, harus terpeuhi 2 rukun :

1. Ilmu (mengetahui dan menyadari), bahwa pelaku akad memahami betul tentang bentuk akad dilakukan dan menyadari konsekuensi akadnya.

15 Departemen Agama RI., al-Qur'an dan Terjemahnya, (Jakarta: Proyek Pengadaan Kitab Suci al-Qur'an, 1984), hlm. 122. 


\section{Jamaluddin | Implementasi Akad Ijarah...}

Tidak ada pihak yang merasa dibohongi dan dibodohi dalam transaksinya, harus saling ridha (ikhlas lahir batin).

2. Al-Ikhtiyar/berusaha (tidak ada paksaan), artinya, tidak ada unsur paksaan dari/oleh siapapun \& dari manapun dalam semua trasaksinya.

Dalam tafsirnya, Ibnul Arabi mengatakan :

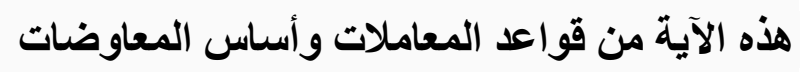

Artinya: Ayat di atas merupakan kaidah baku dalam fiqh muamalah dan prisip dalam akad muawadhat.

Dari Abu Said al-Khudri, Nabi Muhammad saw. bersabda :

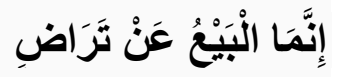

Artinya : Sesungguhnya jual-beli harus dilakukan saling ridha. ${ }^{16}$

Sebagaimana dinyatakan dalam kaidah :

\section{الإكراه يسقط الرضا}

Artinya: Unsur pemasakan (paksaan) dapat menggugurkan ridha (keikhlasan). ${ }^{17}$

Akad muawadhat dibangun di atas prisip pelit, artinya untuk dapat dianggap sebagai akad muawwadhat yang sah, maka masing-masing harus memastikan bahwa pasangannya telah ridha (saling ridha), tidak ada unsur paksaan dalam melakukan transaksi.

Termasuk juga masing-masing pelaku akad harus memahami objek akad dan konsekuensinya. Karena itu dalam akad muawwadhat, semua harus

16 Hadits Riwayat Ibn Majah, Ibn Hibban dan dishahihkan Syuaib al-Arnauth, 2269. 4967

17 Sulaiman ar-Ruhaili, Mudzakarah Qawaid fi al-Buyu', tp. t.th), hlm 117. 
terukur. Sehingga tidak boleh ada transaksi yang mengandung nilai gharar (ketidak jelasan). ${ }^{18}$

IMBT secara terminologis adalah akad ijarah yang disertai janji pemindahan kepemilikan barang sewa (maha al-manfa'ah) pada akhir sewa, baik dipindahkan dengan akad hibah maupun dengan akd jual-beli. ${ }^{19}$

Konsep leasing dan akad IMBT merupakan konsep kombinasi anatara akad dan janji (al-wa'd). Akad-akad yang dikombinasikan adalah akad sewa (ijarah), akad hibah dan akad jual-beli (al-ba'i) yang diselingi dengan janji (wa'd), yaitu janji jual-beli (jual-beli) dan janji hibah dari pihak pemilik barang sewa. ${ }^{20}$

Sarah Binti Adil ibn Muhammad Amin Rauzi menjelaskan tentang adanya 5 (lima) bentuk IMBT, antara lain :

1. IMBT-Ijariyah (ijarah maqrunah bi al-ba'i tsamanuhu al-aqsath aljariyyah), yaitu akad IMBT yang pembayaran ujrahnya dilakukan secara bertahap dan secara serta-merta (dengan sendirinya) barang sewa menjadi milik penyewa apabila penyewa telah melakukan pembayaran angsuran secara penuh, karena pembayaran angsuran setiap bulanya tergabung 2 (dua) unsur : 1) ujrah (harga sewa (akad ijarah), 2) tsaman (harga beli (akad jual-beli) atas barang sewa. Ada beberapa ulama berpendapat bahwa akad IMBT-Jariyah termasuk akad yang tidak jelas (jahalah/gharar), karena alasanya sbb :

${ }^{18}$ Read more https://pengusahamuslim.com/5016-kaidah-dalam-fiqh-jual-beli-bagian09-akad-muaw-wadhat-dibangun-di-atas-prinsip-pelit.html, di akses pada tanggal, 30 Juni 2020 .

19 Wahbah Zuhaili, Muamalat al-Maliyyah al-Mu'asyirah, (Bairut: Dar al-Fikri alMu'ashir, 2002), hlm. 394-395.

${ }^{20}$ Sarah Binti Adil Ibn Muhammad Amin Rauzi, al-Uqud al-Maliyyah al-Mustajaddah wa Dawabithuha: Dirasah Ushuliyyah Tathbiqiyyah, (KSA: Universitass Umm al-Qara, 2010), hlm. 244. 
Jamaluddin | Implementasi Akad Ijarah...

a. Terjadi perbedaan antara formal akad dan subtansinya. Bentuk formalnya akad ijarah, tetapi subtansinya akad jual-beli (berpin-dahnya kepemilikan barang mahal al-manfa'ah)

b. Akad ijarah adalah akad yang pasti penunjukanya, yaitu pemindahan kepemilikan manfaat (ba'i al-manfaah), bukan akad yang menyebabkan berpindahnya kepemilikan barang. Oleh karena itu merupakan kesalahan dalam hal berpindahnya kepemilikan barang dan akad ijarah. Akad ijarah sama sekali tidak dapat dijadikan dasar berpindahnya kepemilikan barang (mahal al-manfaah).

c. Maksud (kehendak) para pihak harus dipastikan dengan jelas, apakah para pihak akan melakukan akad ijarah atau akad jual-beli. Kalau akad ijrah tidak dapat beralih (berpindah) ke jual-beli, sebagaimana teori perpindahan akad (tahawul al-aqd).

d. Pembaran sewa (ujrah) tidak mungkin disatukan dengan pembayaran harga (tsaman). Penyatuannya merupakan ketidakjelasan akad, karena terkesan bahwa akad ini pada awalnya akad ijarah, sedangkan pada akhirnya akad jual-beli ('aqd al-ijarah ibtida' wa 'aqd al-ba'i intiha'). ${ }^{21}$

2. IMBT-Ramzi (al-ijarah al-muqtarinah bi tsaman ramziy), yaitu akad ijarah yang disertai akad jual-beli (mahal al-manfa'at) dengan harga yang berupa rumus (mirip dengan nilai sisa/residu). Dalam hal ini terdapat 2 (dua) akad atas satu obyek yang sama. Akad ijarah dan akad jual-beli dilakukan secara bersamaan dengan harga berupa rumus yang disepakati (mislanya harga residu sebesar $10.5 \%$ dari harga perolehan).

${ }^{21}$ Sarah Binti Adil Ibn Muhammad Amin Rauzi, al-Uqud al-Maliyyah al-Mustajaddah wa Dawabithuha: Dirasah Ushuliyyah Tathbiqiyyah, hlm. 245-251. 
3. IMBT-Haqiqi (al-ijarah al-muqtarinah bi al-bai' bi tsaman haqiqi), yaitu akad ijarah yang disertai jual-beli mahal al-manfaah dengan harga yang sebenarnya, yaitu harga yang berlaku di pasar atau harga berdasar-kan kesepakatan setelah proses negoisasi (tawar-menawar).

4. IMBT-Beli (al-ijarah al-muqtarinah bi wa'd al-bai'), yaitu akad ijarah yang disertai dengan janji untuk jual-beli mahal al-manfa'ah. Dalam hal ini terdapat dua akad dalam fase yang berbeda : 1) fase pertama adalah fase ijarah, 2) fase kedua (setelah selesainya fase ijarah) dilakukan akad jualbeli dengan harga dan syarat sesuai dengan janji yang telah disepakati bersama sebelumnya.

5. IMBT-Hibah (al-ijarah al-muqtarinah bi wa'd al-hibah), yaitu akad ijarah yang disertai dengan janji untuk hibah mahal al-manfa'ah. Dalam hal ini terdapat dua akad dalam fase yang berbeda : 1) fase pertama adalah fase ijarah, 2) fase kedua (setelah selesainya fase ijarah) dilakukan akad hibah dengan syarat sesuai dengan janji yang telah disepakati bersama. ${ }^{22}$

\section{Pandangan Ulama tentang IMBT.}

Para ulama mendiskusikan tentang sah atau tidaknya akad IMBT. Ada 5 (lima) topik penting dalam mengomentari sah atau tidaknya akad IMBT, di antaranya : 1) hukum ta'liq dalam akad, 2) dua akad dalam satu akad, 3) sifat mengikatkan janji secara hukum, 4) penentuan syarat atau beberapa syarat dalam akad mu'awadhat, 5) kaidah ushul mengenai Ijarah Muntahiyah Bittamlik (IMBT). ${ }^{23}$

${ }^{22}$ Sarah Binti Adil Ibn Muhammad Amin Rauzi, al-Uqud al-Maliyyah al-Mustajaddah wa Dawabithuha: Dirasah Ushuliyyah Tathbiqiyyah.

23 Ali Jum'ah Muhammad dkk., Mausu'ah Fatawa al-Muamalat al-Maliyyah li alMasharif wa al-Mu'asasah al-Maliyyah al-Islamiyyah, (Kairo: Dar al-Salam, 2009), vol. IV, hlm. 27. 
Jamaluddin | Implementasi Akad Ijarah...

Lima topik penting para ulama tersebut dalam mengomentari sah atau tidaknya akad IMBT di atas, sebagai berikut :

\section{Hukum al-Ta'liq dalam Akad.}

al-Ta'liq dalam Akad (ta'liq al-uqud) adalah disepakatinya syarat yang bersifat mendatang (mustaqbal), yaitu pihak $\boldsymbol{m u}$ 'jir berjanji kepada musta'jir akan menghibahkan (menjual) mahal al-manfaah kepada musta'jir, dengan syarat telah berakhirnya masa sewa dan/atau mu'jir telah melunasi seluruh kewajibanya yang berupa pembayaran ujrah kepada $\boldsymbol{m} \boldsymbol{u}$ 'jir.

Imam Ahmad Ibn Hambal yang terdapat dalam kitab al-Ikhtiyarat alFiqhiyyah min Fatwa Syeikh al-Islam Ibn Taimiah karya Ali al-Ba'li, berpendapat bahwa ta'liq al-uqud yang berisafat mustaqbal (forward) boleh dan sah, karena berbagai alasan berikut :

a. Hadits riwayat dari Abdullah Ibn Umar r.a. pada saat perang Rasulullah saw. memerintah Zaid ibn Haritsah. Apabila Zaid ibn Haritsah terbunuh, pimpinan pasukan diserahkan kepada Ja'far, apabila Ja'far terbunuh, pimpinan pasukan diserahkan kepada Abdullah Ibn Rawahah. Rasulullah saw. bersabda sbb :

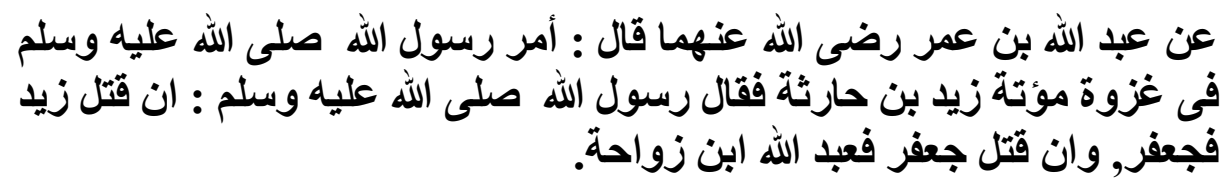

Dalam konteks hadits tersebut di atas, Rasulullah saw. melakukan ta'liq aluqud yang bersifat mustaqbal/istiqbal (masa yang akan datang).

b. Sesungguhnya prinsip penentuan syarat dalam akad adalah boleh dan sah.

c. Ta'liq al-uqud tidak termasuk perbuatan gharar, maisir dan akl al-mal bi al-bathil. Ia tidak termasuk jual-beli mulasamah dan jual-beli munabadzah yang dilarang oleh Rasulullah saw. 
Jamaluddin | Implementasi Akad Ijarah...

\section{Hukum Dua Akad dalam Satu Akad}

Diskusi mengenai hukum kedua dalam IMBT adalah adanya dua transaksi dalam satu akad (shafqatani fi shafqah wahidah (bai'tani fi bai'ah wahidah). Diskusi topik ini, para ulama berbeda pendapat :

a. Jumhur ulama kalangan Hanafiah, Malikiah, Syafi'iah dan Hanabilah, sebagaimana dijelaskan dalam kitab al-Mabsuth, Hasyiyah al-Dusuki ala al-Syarh al-Kabir, al-Majmu' Syarh al-Muhadzdzab dan al-Syarh alKabir melarang dilakukanya akad IMBT, karena terdapat dua transaksi dalam satu akad, karena :

○ Hadits Rasulullah saw. mengenai hal ini, “la yahillu bai' wa salaf” yang artinya, tidak sah melakukan akad tabarru berbarengan dengan akad jual-beli, “la syarthani fi bai'“ artinya, tidak boleh menentukan dua syarat dalam satu jual-beli, "wa la ribha ma lam yudhman"yang artinya tidak berhak mendapatkan keuntungan apabila tidak mau menerima risiko rugi, dan "wa bai' ma laisa indak" yang artinya tidak boleh menjual barang yang bukan milik kamu.

- Hadits Rasulullah saw. riwayat Imam Abu Daud dari Abu Hurairah, “naha Rasulullah saw. an bai'atani fi bai'ah“, artinya Rasulullah saw, melarang melakukanya dua jual-beli dalam satu jual-beli.

b. Ibnu Taimiah, sebagaimana dijelaskan dalam kitab Majmu'at al-Fatawa, beliau berpendapat bahwa adanya dua transaksi dalam satu akad dibolehkan karena :

○ Sesungguhnya prinsip dasar dalam bermuamalah dan penentuan syarat adalah halal dan sah. 


\section{Jamaluddin | Implementasi Akad Ijarah...}

- Akad IMBT terhindar dari hadits mengenai larangan adanya penentuan dua syarat dalam satu akad jual-beli, sebab maksud hadits tersebut adalah bahwa "saya mau menjual barang ini kepada Anda dengan harga sekian, dengan syarat Anda menjualnya kembali kepada saya dengan harga sekian".

- Maksud hadits Rasulullah saw. mengenai dilarangnya melakukan dua jual-beli dalam satu jual-brli adalah jual-beli al-inah. Oleh karena itu,

Ibnu Taimiah menegaskan bahwa akad IMBT dilakukan karena terhindar dari bai' al-inan (bai' al-inah). ${ }^{24}$

Dengan demikian yang dimaksud bai’ al-inan (bai' al-inah) adalah seseorang membeli barang secara tidak tunai, dengan kesepatakan akan menjual kembali kepada penjual pertama dengan harga lebih kecil secara tunai. Demikian juga bahwa pengertian bai' al-inan (bai' al-inah) adalah di definisikan dari aspek pembeli dan aspek penjual. Dari aspek pembeli, bai' alinan (bai' al-inah) adalah seseorang membeli barang secara tidak tunai, dengan kesepakatan akan menjual kembali kepada penjual pertama dengan harga lebih kecil, tetapi tunai. ${ }^{25}$

\section{Mengikatnya Janji secara Hukum}

Dalam akad imbt terdapat unsur janji (al-wa'd), yaitu janji untuk melakukan jual-beli (hibah) pada saat akad ijarah berakhir dengan syarat musta'jir telah melunasi seluruh kewajibanya yang berupa pembayaran ijarah. Dalam hal kewajiban melaksanakan janji, para ulama berbeda pendapat.

\section{Argumentasi dalam Melaksanakan Janji.}

24 Ali Jum'ah Muhammad dkk., Mausu'ah Fatawa al-Muamalat al-Maliyyah li alMasharif wa al-Mu'asasah al-Maliyyah al-Islamiyyah, hlm. 105.

25 Azizi Abu Bakar, Pelaksanaan Bay al-Inah dalam Pembiayaan Peribadi (Personal Loan) di Malaysia, International Conference on Corporate Law (ICCL) 2009 1st - 3rd June 2009, Surabaya, Indonesia, hl. 4 
1. Jumhur ulama dari kalangan Hanafi, Maliki, Syafi'iah, Hanabilah, Dhahiriah dan Jumhur ulama dari kalangan Sahabat dan Tabi'in bahwa hukum melaksanakan janji tidak wajib secara hukum (tidak wajib di laksanakan berdasarkan hukum (qadha'), tetapi diperintahkan untuk dilaksanakan secara moral. Dengan alasan :

a. Al-Qur'an surat at-Taubah ayat $91 \mathrm{sbb}$ :

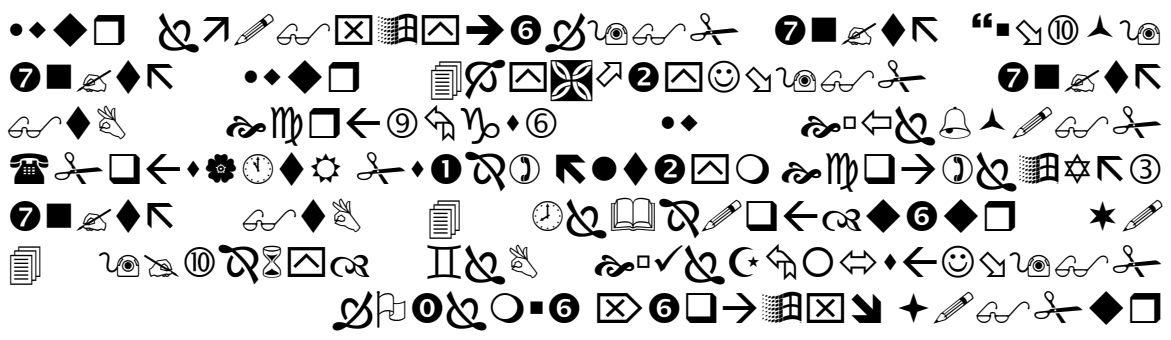

Artinya: "Tiada dosa (lantaran tidak pergi berjihad) atas orang orang yang lemah, orang-orang yang sakit dan atas orangorang yang tidak memperoleh apa yang akan mereka nafkahkan, apabila mereka berlaku ikhlas kepada Allah dan Rasul-Nya, tidak ada jalan sedikitpun untuk menyalahkan orang-orang yang berbuat baik dan Allah Maha Pengampun lagi Maha Penyayang"26 (QS. at-Taubah, 19).

b. Hadits Rasulullah saw. riwayat Imam at-Thabrani tentang hadiah bagi Umi Kultsum binti Abi Salamah.

2. Bebarapa ulama berpendapat bahwa hukum melaksanakan janji adalah wajib secara hukum dengan alasan :

a. Imam Malik, Ibn Qasim dan Suhnun (Abd. Salam Ibn Sa'id alTakhnuki) mengatakan bahwa janji itu bersifat mengikat apabila janji itu bersyarat dan diantara syarat dimaksud sudah mulai dilakukan.

b. Ashbagh Ibn al-Fajr Ibn Sa'id al-Mishri (ulama Malikiah) mengatakan bahwa janji itu bersifat mengikat apabila janji itu bersyarat,

26 Departemen Agama RI., al-Qur'an dan Terjemahnya, (Jakarta: Proyek Pengadaan Kitab Suci al-Qur'an, 1984), hlm. 295 
Jamaluddin | Implementasi Akad Ijarah...

meskipun belum dilakukan, maka harus ditunaikan, dengan alasan kaidah fiqh "la dharar wa la dhirar" (tidak boleh menyulitkan pihak lain dan tidak boleh pula mempersulit oleh pihak lain).

c. Ulama Hanifah sebagaimana dijelaskan dalam kitab Ghamz Uyun alBasha'ir li al-Hawawi, berpendapat bahwa janji bersyarat wajib hukumnya ditunaikan secara hukum.

d. Ibn Syubrumah (hakim di Kuffah) yang wafat pada tahun $144 \mathrm{H}$. sebagaimana dijelaskan dalam kitab al-Muhalla dan al-Furuq serta Ibnu Taimiah, dijelaskan dalam kitab al-Fahriyah min Fatawa Ibn Taimiah, mengatakan bahwa janji itu wajib ditunaikan secara hukum serta mengikat secara mutlak. Dalil yang dapat dijaikan alasan yang menunjuk wajibnya melaksanakan janji adalah :

- Al-Qur'an Surat al-Ma'idah ayat 1, tentang perintah untuk menunaikan (menepati) janji-janjinya, sbb :

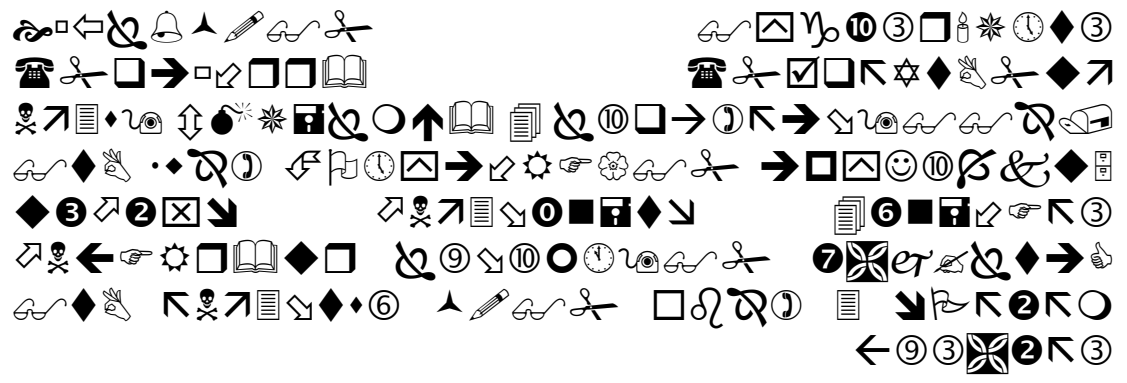

Terjemahnya: "Wahai orang-orang yang beriman, penuhilah aqad aqad itu (aqad (perjanjian) mencakup: janji prasetia hamba kepada Allah dan perjanjian yang dibuat oleh manusia dalam pergaulan sesamanya. Dihalalkan bagimu binatang ternak, kecuali yang akan dibacakan kepadamu. (yang demikian itu) dengan tidak menghalalkan berburu ketika kamu sedang mengerjakan haji. Sesungguhnya Allah menetapkan 
hukum-hukum menurut yang dikehendaki-Nya". ${ }^{27}$ (QS. al-Ma'idah, 1)

○ Al-Qur'an Surat al-Mu'minun ayat 8, tentang ciri-ciri seorang mukmin yang beruntung adalah orang yang menunaikan (menepati) janji-janjinya.

¿ $\rightarrow \Omega$

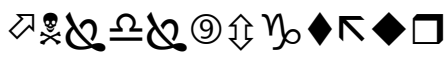

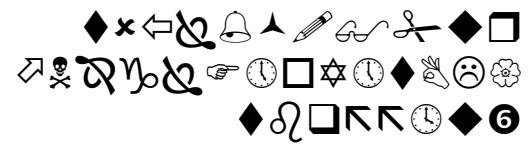

Terjemahnya: “... dan orang-orang yang memelihara amanat amanat (yang dipikulnya) dan janjinya, (ciri-ciri seorang mukmin) "28. QS. al-Mu'minun, 8).

- Al-Qur'an Surat al-Shaf ayat 3, tentang dosa besar adalah tidak melakukan apa yang diucapkan (dijanjikan), sbb :

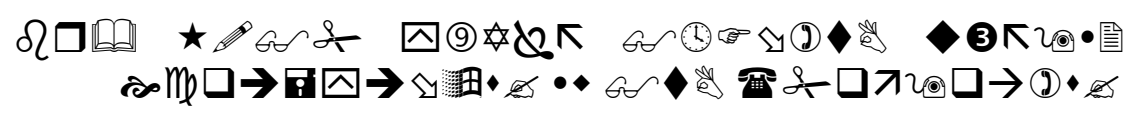

Terjemahnya: “... Amat besar kebencian di sisi Allah bahwa kamu mengatakan apa-apa yang tidak kamu kerjakan" ${ }^{29}$ (QS. al-Shaf 3)

- Hadits Rasulullah saw. dari Abu Hurairah menjelaskan bahwa ingkar janji termasuk perbuata nifaq (munafiq).

\section{Penetuan Syarat dalam Akad Mu'awadhat}

Akad Ijarah Mutahiya Bittamlik (IMBT) terdapat beberapa ketentuan yang berkaitan dengan pemeliharaan obyek sewa yang bersifat ikutan (tabi'yah/muttatabi'), antara lain :

27 Departemen Agama RI., al-Qur'an dan Terjemahnya, (Jakarta: Proyek Pengadaan Kitab Suci al-Qur'an, 1984), hlm. 156

28 Departemen Agama RI., al-Qur'an dan Terjemahnya, hlm. 527

29 Departemen Agama RI., al-Qur'an dan Terjemahnya, hlm. 928 
Jamaluddin | Implementasi Akad Ijarah...

a. Musta'jir harus (wajib) bertanggung jawab atas biaya (nafqah) penjagaan, pemeliharaan dan pengamanan obyek sewa,

b. Mu'jir tidak boleh men-tasaruf-kan obyek ijarah yang dapat mela-hirkan madharat bagi musta'jir (membuat obyek sewa tidak lagi dikuasai oleh musta'jir),

c. Mu'jir menjual obyek sewa kepada musta'jir, apabila kewajibanya telah dilunasi sesuai dengan kesepakatan,

d. Musta'jir memiliki hak untuk memiliki obyek sewa dengan membayar harga tertentu dan telah menyewanya dalam jangka waktu tertentu.

\section{Kaidah Ushul Fiqh dalam IMBT.}

Jumhur ulama ada perbedaan pendapat antara melarang (mengharamkanya) dan membolehkanya. Ibn Taimiah dan Ibn al-Qayyum al-Jauziyyah mengajukan bebarapa kaidah ushul sebagai argumentasi dibolehkanya akad IMBT, sebagai berikut :

a. Kaidah al-Ashl fi al-Asyya'wa al-Muamalat wa al-Syuruth (hukum pokok (prinsip) suatu perbuatan hukum muamalah diperbolehkan bersyarat). Kaidah ini adalah kaidah mengenai bolehnya menyertakan syarat dalam akad $\boldsymbol{m u}$ 'awwadhat, sebagaimana dibolehkan ulama Hanafiah, Malikiah, Syafi'iah dan Hanabilah meskipun mereka berbeda pendapat mengenai periicianya.

b. Kaidah ma la yatim tark al-haram illa bi tarkihi fa tarkuhu wajib (sesuatu yang tidak sempurna untuk meninggalkan perbuatan haram, kecuali dengan meninggalkanya, maka hukum meninggalkanya adalah wajib). Kaidah ini dianggap sebagai penguat terhadap pendapat yang membolehkan akad IMBT karena akad ini dibentuk untuk menghindari perbuatan haram, yaitu berbilangnya akad yang haram. 
c. Kaidah al-bathil wa al-fasid (akad yang batal dan fasid). Kaidah ini merupakan dasar bahwa suatu akad tidak boleh didasarkan pada alasan (argumentasi) tertentu. Kebatilan (ke-fasid-an) tertentu akad akan hilang apabila unsur (sebab/illat) yang menjadi dasar batalnya akad telah hilang (aqd yumkin tashhuhu bi izalat ma afsadah) akad yang batil dan fasid memungkinkan menjadi sah setelah dihilangkan nya sebab kebatilanya (kefasid-annya).

d. Kaidah al-hajah tanzil manzilat al-dharurah (keadaan terpaksa al-hajat menempati posisi kemadharatan). Ibn qayyim al-jauziyyah menbolehkan akada IMBT karena akad ini dibutuhkan masyarakat, sehingga masyarakat akan terhindar dari masyaqqah. Kebolehkanya merupakan upaya menghilangkan kesulitan (raf' al-haraj) dan memudahkan (al-taisir).

e. Kaidah ibthal al-hiyal (hilah hukum harus bibatalkan). Kaidah ini sebagai upaya untuk mengurai bahwa IMBT merupakan akad yang berada antara ijarah dan akad jual-beli (hibah), karena terjadi perbedaan antara formal akad dan subtansinya. Formalnya akad ijarah, sedangkan subtansinya adalah akad jual-beli (hibah). Ibn Taimiah dan Ibn Qayyim al-Jauziyyah menegaskan bahwa akad IMBT tidak termasuk hibah, karena kehendak para pihak yang berakada adalah akad mu'awwadhat (bukan akad tabarru') dan penyertaan akad jual-beli (hibah) kepada akad ijarah merupakan wasilah yang di perbolehkan. ${ }^{30}$

\section{Huurkoop (Sewa-Jual)}

Pengertian huurkoop (sewa-jual) adalah sewa-jual/jual dengan cara sewa/jual-beli dengan mengungsur. Seseorang (namanya Abdun) penerima

\footnotetext{
30 Jaih Mubarok dan Hasanudin, Fiqh Muamalah Malyyah : Akad Ijarah dan Ju'alah, hlm. 109.
} 
Jamaluddin | Implementasi Akad Ijarah...

sewa, dan seseorang (namanya Zaid) pemberi sewa, kedua belah pihak melakukan akad sewa atas sebuah kendaraan mobil (roda empat) setiap bulan sewanya Rp. 10.000.000,- (sepuluh juta) rupiah, selama 12 bulan (1 tahun) dengan kesepakatan sebagai berikut :

1. Apabila bapak Abdun telah membayar sejumlah Rp. 10.000.000,(sepuluh juta) rupiah kepada bapak Zaid selama 12 kali berturut-turut, maka kendaraan tersebut menjadi milik bapak Abdun selamanya.

2. Apabila bapak Abdun gagal (bayar) menunaikan janjinya (untuk membayar sejumlah uang Rp. 10.000.000,- kepada bapak Zaid selama 12 bulan (misalnya gagal bayar selama 1 bulan), maka bapak Zaid dapat mengambil kembali kendaraan tersebut serta uang yang telah diterima oleh bapak Zaid dari bapak Abdun selama 11 bulan x Rp. 10.000.000= Rp. 110.000.000,- (11 bulan) diakui sebagai pembayaran sewa (ujrah), bukan sebagai pembayaran harga (tsaman).

Demikian penjelasan huurkoop (sewa-jual) yang termasuk kategori masalah dunia yang hukum asalnya adalah boleh (al-ibahah), bahwa tidak menemukan dalil yang mengharamkan huurkoop (sewa-jual). Oleh karena itu ketiadaan dalil yang cukup untuk dijadikan alasan mengenai bolehnya melakukan huurkoop (sewa-jual). ${ }^{31}$

\section{Kesimpulan}

Dari uraian tersebut di atas, maka dapat disimpulan bahwa akad Ijarah Muntahiyah bi al-Tamlik (IMBT) dapat dijalankan oleh Lembaga Keuangan Syariah (LKS) dan bank maupun non bank syariah, sesuai dengan fatwa DSNMUI Nomor 27 Tahun 2002 \& Hukum Islam sebagai berikut :

31 A. Hasan, Soal-Jawab tentang Berbagai Masalah Agama, (Bandung: CV Diponegoro, 1988), vol. II, hlm. 667-668. 
1. Akad Ijarah Muntahiyyah bi al-Tamlik (IMBT) termasuk akad mustahdatsah (mustajaddah) akad baru yang diduga kuat hasil interaksi antara figh dan pranata bisnis leasing yang hidup dan berkembang di masyarakat yang menyebut perjanjian leasing sebagai pranata "banci" karena mengandung 2 (dua) unsur hukum yang berbeda : 1) unsur sewamenyewa, sebagaimana diatur dalam KUHPerdata, 2) unsur jual-beli (albai') yang juga diatur dalam KUHPerdata juga dalam bab dan pasal yang berbeda-beda.

5. Dalam perspektif teori perjanjian, akad IMBT pada prinsipnya merupakan perpaduan antara akad mu'awadhat dan akad tabarru' (akad hibah) yang diselingi dengan janji bersyarat (wa'd bi syarth).

6. Secara konseptual, leasing merupakan titik temu antara akad sewa dan akad jual-beli. Sedangkan dalam perspektif khasanah fiqh, akad ijarah dikembangkan menjadi akad Ijarah Muntahiyyah bi al-Tamlik (IMBT).

7. Akad Ijarah Muntahiya bi al-Tamlik (IMBT) sesungguhnya akad yang sophisticated (canggih), karena dapat digunakan untuk berbagai macam produk perbankan syariah, setidaknya dapat digunakan untuk \pm 15 (lima belas) macam produk perbankan syariah, diantaranya : refinancing, working capital, take over (top up), KPRS Indent, investasi indent, penagihan hutang dari bank konvensional ke bank syariah, restruk-turisasi pembiayaan (konversi akad), capital expenditure (investasi), reimbursement, pembiayaan konsumtif untuk Kredit Pemilikan Rumah Syariah, (KPRS), dll. 
Jamaluddin | Implementasi Akad Ijarah...

\section{Daftar Pustaka}

Ahmad Hasan, Nazhariyyat al-Ujur fi al-Fiqh al-Islami: Dirasah Tahliliyyah Mubtakirah li-Fiqh al-Muamalat al-Maliyah, Damaskus: Dar alIqra', t.th.

Ali Jum'ah Muhammad dkk., Mausu'ah Fatawa al-Muamalat al-Maliyyah li al-Masharif wa al-Mu'asasah al-Maliyyah al-Islamiyyah, vol. IV Kairo: Dar al-Salam, 2009.

Amin Widjaya Tunggal dan Arif Johan Tunggal, Aspek Yuridis dalam Leasing. Jakarta: PT Renika Cipta, 2001.

Azizi Abu Bakar, Pelaksanaan Buy Al-Inah dalam Pembiayaan Pribadi (Personal Loan) di Malaysia, International Conference on Corporate Law (ICCL), 2009 1st- $3^{\text {rd }}$ June 2009, Surabaya, Indonesia.

A. Hasan, Soal-Jawab tentang Berbagai Masalah Agama, vol. II, Bandung: CV Diponegoro, 1988.

Al-Ma'asyir al-Syar'iyyah, Bahrain: Hai' at al-Muhasabah wa al-Muraja'ah li al-Mu'assasat al-Maliyah al-Islamiyyah, 2006.

Departemen Agama RI., al-Qur'an dan Terjemahnya, Jakarta: Proyek Pengadaan Kitab Suci al-Qur'an, 1984.

Dewan Syariah Nasional Majelis Ulama Indonesiai (DSN-MUI), Jakarta: ditetapkan di Jakarta, tanggal 14 Muharram 1423 H/28 Maret 2002 M.

Hadits Riwayat Ibn Majah, Ibn Hibban dan dishahihkan Syuaib al-Arnauth, t.tp, t.th.

Jaih Mubarok dan Hasanudin, Fiqh Muamalah Malyyah : Akad Ijarah dan Ju'alah, Bandung: Simbiosa Rekatama Media, 2017. 
Jamaluddin | Implementasi Akad Ijarah...

Muhammad Yusuf Arif al-Haj Muhammad, Aqd al-Ijarah al-Muntahiyyah bi al-Tamlik min al-Tathbiqat al-Mu'ashirah li Aqd al-Ijarah fi Fiqh al-Islami, Gazza: Universitas al-Najah al-Wathaniyyah, 2003.

Munir Fuady, Hukum tentang Pembiayaan dalam Teori dan Praktik, Bandung: PT Citra Aditya Bakti, 2002.

Rastono, Penerapan Prinsip Bagi Hasil dalam Pembiayaan Terhadap Nasabah Bank Syariah, Tesis tidak diterbitkan, Semarang, Fakultas Hukum Universitas Diponegoro, 2008.

Readmore https://pengusahamuslim.com/5016-kaidah-dalam-fiqh-jualbelibagi an-09-akad-muaw-wadhat-dibangun-di-atas-prinsippelit.html, di akses pada tanggal, 30 Juni 2020.

Sarah Binti Adil Ibn Muhammad Amin Rauzi, al-Uqud al-Maliyyah alMustajaddah wa Dawabithuha: Dirasah Ushuliyyah Tathbiqiyyah, KSA: Universitass Umm al-Qara, 2010.

Sulaiman ar-Ruhaili, Mudzakarah Qawaid fi al-Buyu', tp. t.th.

Soerjono Soekanto dan Mustafa Abdullah, Sosiologi Hukum Masyarakat dalam Masyarakat, Jakarta: Rajawali Pers, 1987.

Undang-undang Nomor 21 Tahun 2008 tentang Perbankan Syariah, pasal 19 ayat (1) huruf f, ayat (2) huruf f dan pasal 21 huruf b4.

Wahbah Zuhaili, Muamalat al-Maliyyah al-Mu'asyirah, Bairut: Dar al-Fikri al-Mu'ashir, 2002. 